\title{
Rice Blast Epidemics Initiated by Infested Rice Grain on the Soil Surface
}

\author{
D. H. Long, Field Research Biologist, Zeneca Ag Products, Southern Regional Technical Center, Leland, MS \\ 38756; J. C. Correll, Professor, Department of Plant Pathology, University of Arkansas, Fayetteville 72701; F. N. \\ Lee, Professor, Rice Research and Extension Center, Stuttgart, AR 72160; and D. O. TeBeest, Professor, \\ Department of Plant Pathology, University of Arkansas, Fayetteville 72701
}

\begin{abstract}
Long, D. H., Correll, J. C., Lee, F. N., and TeBeest, D. O. 2001. Rice blast epidemics initiated by infested rice grain on the soil surface. Plant Dis. 85:612-616.

Field experiments were conducted in 1996 and 1997 with a marked strain of Pyricularia grisea to determine if inoculum from infested rice grain could cause primary infections and sustain a rice blast epidemic during the growing season by giving rise to leaf, collar, and neck symptoms. The marked strain, a sulfate nonutilizing ( $\mathrm{sul}$ ) mutant of $P$. grisea, was grown on autoclaved rice seed for 7 days at $25^{\circ} \mathrm{C}$. Infested rice grains were applied to the soil surface at the time of plant emergence (approximately 10 days after planting) at densities of $0,0.5,5,25$, and 50 grains per $0.1 \mathrm{~m}^{2}$ in plots planted to the blast susceptible cv. M-201. Leaf blast symptoms were first detected in the plots containing infested grain 35 days after plant emergence in both 1996 and 1997. The sul mutant was isolated from more than $90 \%$ of the lesions sampled from rice seedlings 35 to 45 days after plant emergence. Leaf blast increased more rapidly in plots with 25 and 50 infested grains per $0.1 \mathrm{~m}^{2}$ than in plots with less inoculum pressure $(0.5$ and 25 infested grains per $0.1 \mathrm{~m}^{2}$ ), although in 1996, leaf blast incidence recorded at midseason in plots containing 0.5 and 5 infested grains per $0.1 \mathrm{~m}^{2}$ was 41 and 55\%, respectively. At the end of both seasons, the sul mutant was recovered from over $90 \%$ of the leaf, collar, and neck blast lesions except for one sample date in 1996. Rice blast was not detected in the control plots (no infested grain) in 1997 and not until 65 days after planting in 1996. Comparisons of disease progress on leaves between the marked strain and the parental wild-type strain under field conditions indicated that development of disease caused by the sul mutant was similar to disease caused by the wild-type strain.
\end{abstract}

Rice blast, caused by the fungal pathogen Pyricularia grisea Sacc. (Magnaporthe grisea [Hebert] Barr.), is one of the most destructive diseases of rice (Oryza sativa $\mathrm{L}$.) worldwide. Rice blast can cause substantial reductions in yield $(15,25$, 26,30,32). P. grisea can infect rice at all developmental stages, causing leaf, collar, neck, and panicle blast symptoms $(15,25$, 32). Rice blast is most severe in temperate and subtropical ecosystems, but it can become severe in other environments if blast susceptible cultivars are widely grown or if effective management strategies are not implemented $(6,11,13-15,20,25,32)$.

\section{Corresponding author: D. O. TeBeest}

E-mail: dtebeest@comp.uark.edu

Portion of a $\mathrm{Ph}$.D. dissertation submitted by the senior author in partial fulfillment of the requirements of the University of Arkansas.

Research supported in part by a grant from the Arkansas Rice Research Promotion Board.

Published with the approval of the Director of the Arkansas Agricultural Experiment Station manuscript no. 99042 .

Accepted for publication 16 February 2001.

Publication no. D-2001-0402-01R

(C) 2001 The American Phytopathological Society
Van der Plank (31) noted that primary inoculum sources contribute to the early onset of disease and greatly influence the intensity of an epidemic and subsequent yield loss. The importance of seedborne inoculum as an overwintering source of primary inoculum has been described for a number of important plant diseases $(3,8,9$, $17,21,23,24,28,29)$. In temperate regions, infested rice seed, rice straw, and rice residue have been implicated as important overwintering sources of primary inoculum, although their impact on initial disease development and the spatial distribution of rice blast is not fully understood $(1,5,6,15,18,19,21,25)$. Although some investigators have suggested that $P$. grisea can move systemically within a seedling from an infested seed, systemic movement has not been demonstrated experimentally $(5,15,18,21,22,25)$. Manandhar et al. (21) and Lamey (18) reported that the frequency of infection per transmission from seed to seedling was generally low; however, seednot covered or loosely covered with soil. Sporulation of $P$. grisea on shallow-planted infested rice seed has been observed on seed at or near the soil surface, and may be an important source of primary inoculum that could initiate rice blast epidemics (1, 5,7 ). These findings have resulted in much debate regarding the role of infested seed as a primary inoculum source, because ing infection was greater when seed were much of this work was conducted under controlled laboratory conditions where $P$. grisea did not have to survive or compete with other soilborne microbes in the soil matrix under anaerobic conditions $(15,25)$.

Lee (19) studied several potential primary inoculum sources in Arkansas and concluded that the rice blast pathogen could survive on infested rice seed and rice residue. These sources may be responsible for primary infection the following year. In Arkansas, seed is commonly found on the soil surface after planting, particularly on levees and along the edges of fields (D. O. TeBeest and D. H. Long, unpublished data). Seed located on the soil surface often do not germinate due to lack of moisture or damage by birds. Birds commonly feed on exposed seed and leave the seed coats behind on the soil surface (11). Thus, $P$. grisea could sporulate on infested seed (or seed coats) on the soil surface under field conditions, and the dissemination of conidia by wind, rain, or physical contact with healthy seedlings could initiate infections on seedlings, and consequently serve as a source of primary inoculum. To test this hypothesis, three specific objectives were pursued in this study: (i) to determine if blast-infested rice grain placed on the soil surface could serve as a primary inoculum source and initiate rice blast epidemics; (ii) to determine if the amount of inoculum (amount of infested grain per 0.1 $\mathrm{m}^{2}$ ) deployed at plant emergence could affect the incidence and development of leaf blast; and (iii) to determine if inoculum originating from infested grain could perpetuate throughout the season and result in late season leaf, collar, and neck blast.

\section{MATERIALS AND METHODS}

Isolates. Cultures of a wild-type isolate (race IC17, isolate 18) and a sulfate nonutilizing mutant (sul) generated from the wild-type parental strain (designated 18/1) were grown on rice bran agar (RBA) (20 g of rice bran, $15 \mathrm{~g}$ of agar, and 1 liter of distilled water) and incubated for 7 days at $24^{\circ} \mathrm{C}$ with $16 \mathrm{~h}$ of light $(20 \mathrm{~W}$ blacklight; Sylvania) per day. Two isolates of $P$. grisea were used in these studies to compare fitness characteristics of the sul mutant (isolate $18 / 1$ ) to its parental wild-type isolate (isolate 18) under field conditions. The sul mutant could readily be distinguished from wild-type isolates (background inoculum) recovered from field material by their growth in petri plates on RBA amended 
with $0.1 \%$ sodium selenate. sul mutants of $P$. grisea grew normally on the sodium selenite-amended RBA plates, whereas wildtype isolates were restricted in growth (10).

Inoculum preparation. Inoculum of a wild-type parental isolate of $P$. grisea (isolate 18, race IC-17) and sul (isolate 18/1) (10) were each grown on autoclaved ' $\mathrm{M}$ 201 ' rice seed for 7 days at $24^{\circ} \mathrm{C}$ with $16 \mathrm{~h}$ of light ( $20 \mathrm{~W}$ blacklight) per day. To prepare the inoculum, $200 \mathrm{~g}$ of dry 'M-201' seed was sterilized in a 1-liter flask by autoclaving for $30 \mathrm{~min}$. After seed were sterilized, $20 \mathrm{ml}$ of sterile, distilled $\mathrm{H}_{2} \mathrm{O}$ was added per flask. Autoclaving dry seed and limiting the sterilization time to only 30 min helped maintain seed integrity (autoclaved seed were visibly similar to nonsterilized seed). Twenty agar plugs (5 $\mathrm{mm}$ ) from 7-day-old cultures were transferred aseptically to each flask. Each flask was then shaken vigorously for $30 \mathrm{~s}$ to mix mycelial plugs throughout the grain. To limit the extent of colonization on the autoclaved grain, the incubation period was limited to only 7 days. After 7 days, colonized grain was allowed to air dry and was stored at $4^{\circ} \mathrm{C}$ until use (approximately 4 to 7 days).

Field experiments. Field experiments were conducted at the University of Arkansas Pine Tree Branch Experiment Station at Colt, AR in 1996 and 1997. The experimental sites were precision-leveled fields bordered by trees on the north side. Blast susceptible cv. M-201 was drilled-seeded at $125 \mathrm{~kg} / \mathrm{ha}$ in plots $(1.5 \times 4.8 \mathrm{~m})$ containing nine planting rows with $17.5-\mathrm{cm}$ row spacing. Each plot was surrounded by barrier plots $(125 \mathrm{~kg} / \mathrm{ha}$ in $3.2-\times 4.8-\mathrm{m}$ plots of 18 rows) of 'Kaybonnet', a cultivar resistant to race IC17, to reduce movement of inoculum between plots. Experiments were planted on 15 April 1996 (seedling emergence 25 April 1997) and 6 May 1997 (seedling emergence 15 May 1997). Treatments consisted of different densities $(0,0.5,5,25$, or 50 grains per 0.1 $\mathrm{m}^{2}$ ) of rice grain infested with the sul mutant applied to the soil surface at the time of plant emergence (approximately 10 days after planting). The treatments were arranged in a randomized complete block design with four replications. Within the same randomization, a 50 infested grain per $0.1-\mathrm{m}^{2}$ treatment using the wild-type isolate was used to compare disease development relative to the sul mutant under field conditions.

All plots were fertilized as recommended with $175 \mathrm{~kg} / \mathrm{ha}$ of urea applied as a single preflood application at initial tillering stage (11). A 4- to 6-cm irrigation flood was applied 21 days after plant emergence, but was drained after 10 days to enhance conditions for rice blast development (15, 20,25). A permanent irrigation flood was applied 41 days after plant emergence and was maintained at a depth of 4 to $6 \mathrm{~cm}$ until harvest.
Sporulation on rice grain. The sporulation of $P$. grisea on infested rice grain placed on the soil surface was assessed weekly for 4 weeks $(0,1,2,3$, and 4 weeks) after application. Ten grains were arbitrarily collected from the soil surface the day the infested grains were applied to the soil surface and stored at $4^{\circ} \mathrm{C}$ overnight. The next day, grains were placed on moistened filter paper in glass petri dishes, incubated at $100 \%$ relative humidity for 36 $\mathrm{h}$ at $24^{\circ} \mathrm{C}$, and examined for sporulation of $P$. grisea with a stereoscope $(\times 40)$. The percentage of grains that had signs of conidetermined after $36 \mathrm{~h}$. Sporulation was quantified by counting conidia of $P$. grisea from 20 incubated grain from each of four replications in $2 \mathrm{ml}$ of water. The rice grain were vortexed for $10 \mathrm{~s}$ after which 5 to 10 samples $(\approx 20 \mu \mathrm{l})$ of the solution were recovered. The number of conidia in the solution was counted with a hemacytometer and was used to calculate the approximate number of conidia per grain.

Disease incidence. Leaf blast incidence was measured weekly as the percentage of plants that had one or more rice blast lesion. Incidence was determined by surveying all plants in the center three rows of each plot of each treatment (approximately 1,000 plants per plot) until disease incidence reached levels of $>1 \%$ in the 25 and 50 infested grain per $\mathrm{m}^{2}$ treatments. After incidence was $>1 \%, 12$ or 25 randomly selected plants in each plot were examined in 1996 and 1997, respectively, to estimate disease incidence.

Comparison of maximum incidence of leaf blast at the panicle primordia stage was statistically analyzed using the general linear models and protected least signifycant difference (LSD) procedures in SAS (SAS Institute, Cary, NC). Degree-day thermal units (DD50s) were calculated each year to estimate the physiological maturity of 'M-201' plants throughout the season by the following formula: DD50 = [(maximum daily temperature + minimum daily temperature)/2] - 50. Accumulations of DD50 units are used in Arkansas to predict the physiological maturity of rice throughout a growing season and, thus, aid in the timing of key management practices diophores and conidia of $P$. grisea was

(11). The accuracy of this prediction is dependent on the maximum temperatures being lower than $34.4^{\circ} \mathrm{C}$ and the minimum temperature being $21.1^{\circ} \mathrm{C}$ or less. Maximum temperatures that are higher than $34.4^{\circ} \mathrm{C}$ were entered as $34.4^{\circ} \mathrm{C}$ and minimum temperatures greater than $21.1^{\circ} \mathrm{C}$ were entered as $21.1^{\circ} \mathrm{C}(11)$. Most rice cultivars grown in Arkansas are fully mature between 2,500 to 3,500 DD50 units.

In order to determine the proportion of lesions caused by the sul mutant, approximately 50 lesions were collected five times during each season from leaves, collars, and necks. Lesions were incubated on moistened filter paper in petri dishes for 24 h. Conidia were transferred onto RBA and incubated for 7 days as previously described. After 7 days, $P$. grisea isolates were transferred to RBA amended with $0.1 \%$ sodium selenate and incubated at $24^{\circ} \mathrm{C}$ as previously described. Growth of colonies greater than $10 \mathrm{~mm}$ after 4 days on RBA amended with sodium selenate confirmed the isolate was a sul mutant; wild-type isolates (background inoculum) of $P$. grisea were greatly restricted (colony diameter $<1 \mathrm{~mm}$ ) on the RBA medium amended with sodium selenate after 4 days. The original wild-type and sul mutant isolates were grown as controls.

\section{RESULTS}

Sporulation on infested grain. Sporulation of $P$. grisea was detected for 3 weeks after spreading infested grain onto the soil surface in 1996, but for only 2 weeks in 1997. In 1996, sporulation on the grain declined from a mean of 100 conidia per grain to 10 conidia per grain after 1 week. The range in the number of conidia per grain in 1996 was 50 to 250 conidia at the time of application and 0 to 30 conidia per grain after 1 week. The mean number of conidia per grain was six (ranging from 0 to 10 conidia) and 0.7 (ranging from 0 to 3 conidia) after 2 and 3 weeks, respectively. Conidia or conidiophores of $P$. grisea were not observed after 3 weeks. Similarly, the number of conidia recovered from the infested grain in 1997 declined from a mean high of 400 conidia per grain detected at the time of deployment to two conidia per grain after 2 weeks. Isolation of conidia

Table 1. Frequency of recovery of a sulfate nonutilizing ( $\mathrm{sul}$ ) mutant of Pyricularia grisea from infested grain and from leaf, collar, and neck lesions for rice cv. M-201 in field experiments in 1996 and 1997

\begin{tabular}{|c|c|c|c|c|c|c|c|}
\hline \multicolumn{4}{|c|}{1996} & \multicolumn{4}{|c|}{1997} \\
\hline $\begin{array}{l}\text { Sample } \\
\text { date }\end{array}$ & Lesion type & $\begin{array}{c}\text { Sample } \\
\text { number }^{\mathrm{a}}\end{array}$ & $\% s u l^{\mathrm{b}}$ & $\begin{array}{l}\text { Sample } \\
\text { date }\end{array}$ & Lesion type & $\begin{array}{c}\text { Sample } \\
\text { number }^{\mathrm{a}}\end{array}$ & $\% s u l^{\mathrm{b}}$ \\
\hline $4 / 28 / 96$ & Infested seed & 20 & $100 \%$ & $5 / 19 / 97$ & Infested seed & 20 & $100 \%$ \\
\hline $6 / 19 / 96$ & Leaf blast & 25 & $96 \%$ & 7/07/97 & Leaf blast & 25 & $100 \%$ \\
\hline $7 / 04 / 96$ & Leaf blast & 50 & $90 \%$ & $7 / 14 / 97$ & Leaf blast & 25 & $100 \%$ \\
\hline $7 / 19 / 96$ & Leaf blast & 50 & $85 \%$ & $8 / 02 / 97$ & Leaf blast & 50 & $98 \%$ \\
\hline 7/19/96 & Collar rot & 25 & $84 \%$ & $8 / 02 / 97$ & Collar rot & 10 & $100 \%$ \\
\hline $8 / 14 / 96$ & Neck blast & 100 & $5 \%$ & $8 / 27 / 97$ & Neck blast & 50 & $90 \%$ \\
\hline
\end{tabular}

a Number of lesions (or seed) examined per sampling date.

b Percentage of lesions from which the sul mutant was recovered. 
from infested rice grain collected from the soil surface the first week after deployment confirmed that the sul mutant $(100 \%$ sul recovery in 1996 and 1997) was the only isolate on the deployed rice grains (Table 1). No isolations were made from grain within the wild-type plots.

Disease incidence. In 1996 and 1997, disease progress in plots infested with the sul mutant and the wild-type isolate of $P$. grisea at 50 infested grain per $0.1 \mathrm{~m}^{2}$ were similar (Fig. 1). In 1996, disease incidence increased rapidly in plots containing either the sul mutant or the wild-type isolate (apparent infection rates of 0.29 and 0.27, respectively) (data not shown) 0 to 60 days after emergence, peaked in leaf blast incidence after 60 days (disease incidence of 83 and $78 \%$, respectively) ( $\operatorname{LSD}_{\alpha=0.05}=$ 0.01 ), and declined between 60 to 90 days after emergence (Fig. 1). Disease incidence caused by either the sul mutant or its parental wild-type isolate of $P$. grisea in plots treated with 50 infested grain per 0.1 $\mathrm{m}^{2}$ was not significantly different (Fig. 1). Leaf blast incidence at midseason in 1997 was less than that observed at midseason in 1996. Leaf blast incidence at midseason was less than $1 \%$ in the 0.5 and 5 infested grain per $0.1-\mathrm{m}^{2}$ plots and only 3 and $25 \%$ leaf blast incidence in the 25 and 50 infested grain per $0.1-\mathrm{m}^{2}$ plots, respectively (Table 2). As in 1996, apparent infection rates ( 0.15 and 0.14 , respectively) (data not shown) and maximum disease incidence (21 and $18 \%$, respectively)
$\left(\operatorname{LSD}_{\alpha=0.05}=7\right)$ were not significantly different between the sul and wild-type isolates (Fig. 1).

In 1996 and 1997, leaf blast symptoms were first detected on rice seedlings 35 days after plant emergence, although plant maturities were quite different between the 2 years due to differences in temperature. Accumulated DD50 was 740 and 1,062 units in 1996 and 1997, respectively (Figs. 1 and 2). Thus, in 1996, leaf blast symptoms were detected after 35 days when the plants were in the early vegetative (active tillering) stages of growth, whereas in 1997 the plants were in the early reproductive (panicle primordia) stages after 35 days.

In 1996, blast developed on plants in all treatments. The maximum incidence of the disease was $41,55,75$, and $85 \%$ in plots treated with $0.5,5,25$, or 50 infested grain per $0.1 \mathrm{~m}^{2}$, respectively (Fig. 2; Table 2). Maximum disease incidence increased significantly as inoculum density was increased from 0.5 to 50 infested grains per $0.1 \mathrm{~m}^{2}$. Blast $(<1 \%)$ was detected in the control plots ( 0 infested grain) 56 days after seedling emergence. Lesions collected from the control plots were caused by the sul mutant.

In 1997, blast developed on plants within all inoculated treatments, but disease incidence was less than $1 \%$ in the 0.5 and 5 infested grain per $0.1-\mathrm{m}^{2}$ treatments (Fig. 2; Table 2). Leaf blast incidence was significantly higher in plots treated with 50 infested grain per $0.1 \mathrm{~m}^{2}(21 \%)$ than in

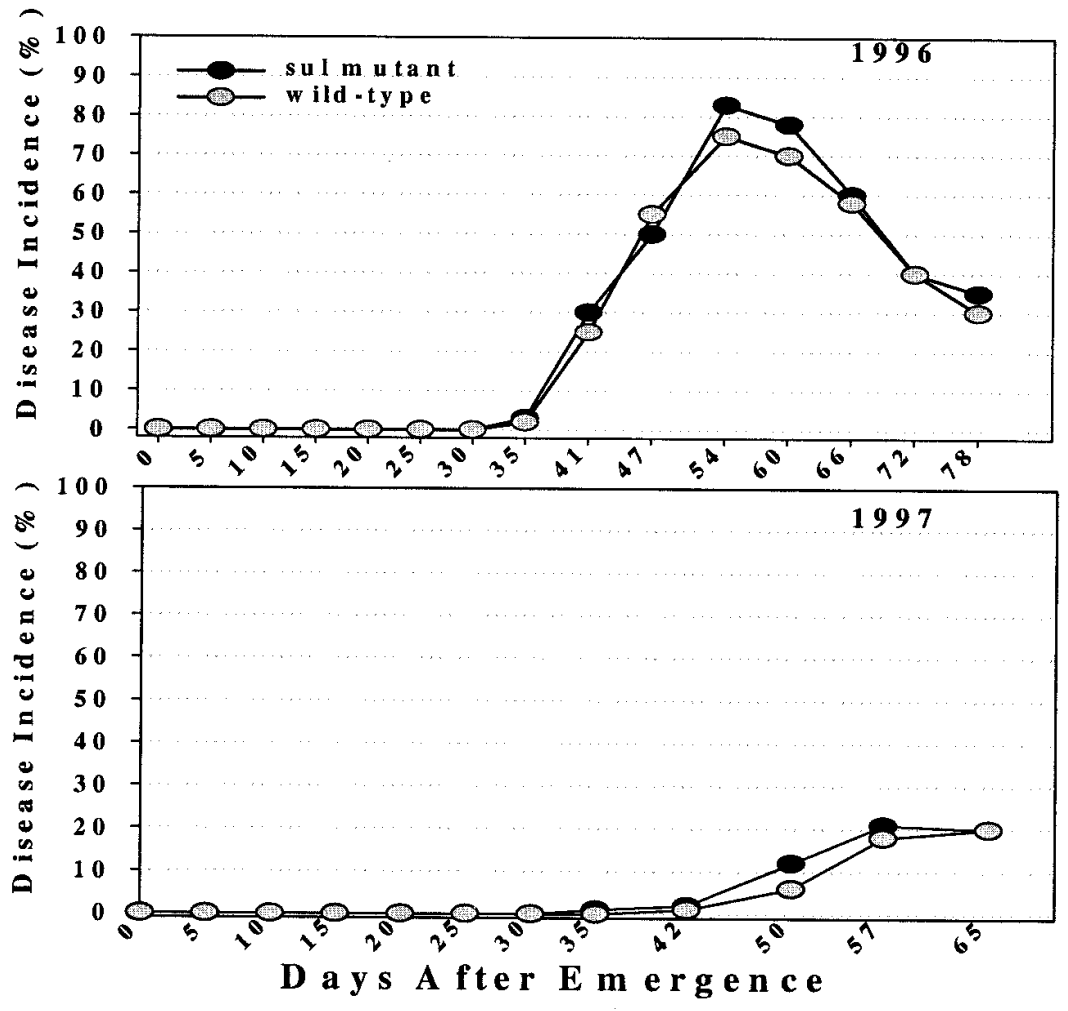

Fig. 1. Disease progress for leaf blast incidence (percent) on 'M-201' for the sulfate nonutilizing (sul) mutant and wild-type isolate of Pyricularia grisea (50 infested grains per $0.1-\mathrm{m}^{2}$ treatment) in 1996 and 1997. plots treated with $0.5,5$, and 25 infested grain per $0.1 \mathrm{~m}^{2}(<1,<1$, and $3 \%$ disease incidence, respectively) (Fig. 2).

In 1996 and 1997, leaf, collar, and neck blast lesions were randomly collected from plots and examined to determine the frequency of recovery of the sul mutant (Table 1). In 1996, the sul mutant was recovered from more than $90 \%$ of the leaf blast lesions collected throughout the season and from more than $80 \%$ of the collar rot lesions (Table 1). Only 5\% of the isolates recovered from neck blast lesions in 1996 were the sul mutant. In 1997, the frequency of sul mutants recovered from all samples was greater than $90 \%$ (Table 1).

\section{DISCUSSION}

Few studies have directly addressed the importance of seed as a source of primary inoculum for the rice blast under field conditions $(1,5,6,18)$. Differentiating between seedborne and background inoculum from other sources has always been a problem in addressing the importance of seedborne inoculum in the overall epidemiology of rice blast. In this study, the use of a marked strain (a sul mutant) of $P$. grisea confirmed the nonsystemic aerial transmission of conidia from artificially infested grain inoculum to rice seedlings and showed that infested seed could initiate rice blast. The transmission of $P$. grisea from infested grain indicates that under field conditions the dissemination of conidia to rice seedlings for up to 2 weeks from an inoculum source on the soil surface was important in the early season epidemiology of rice blast in Arkansas. Furthermore, the marked strain was recovered throughout the season from leaf, collar, and neck infections under field conditions in 1996 and 1997, further emphasizing the importance of the artificially infested grain as a source of primary inoculum.

Naturally infested seed have been reported in randomly selected seed lots in Arkansas (19) with the infestation ranging up to $10 \%$ (D. O. TeBeest, unpublished

Table 2. Maximum incidence of leaf blast caused by Pyricularia grisea recorded at midseason at the panicle primordia stage of growth in 1996 and 1997

\begin{tabular}{lcc}
\hline & \multicolumn{2}{c}{$\%$ Disease $^{\mathbf{b}}$} \\
\cline { 2 - 3 } Inoculum density $^{\mathbf{a}}$ & $\mathbf{1 9 9 6}$ & $\mathbf{1 9 9 7}$ \\
\hline 0 & 0 & 0 \\
0.5 & 41 & $<1$ \\
5 & 55 & $<1$ \\
25 & 75 & 3.0 \\
50 & 83 & 21 \\
LSD $(0.05)^{\mathrm{c}}$ & 8 & 3 \\
\hline a & Number of infested rice grains per $0.1 \mathrm{~m}^{2}$ \\
(sulfate nonutilizing [sul] mutant of $P$. grisea) \\
on the soil surface. \\
b The percentage of plants with at least one \\
lesion recorded at midseason. \\
c Protected least significant difference (LSD) at \\
\multicolumn{2}{c}{$\alpha=0.05$ for each year. }
\end{tabular}


data). Seed has commonly been observed on the soil surface after planting under field conditions ranging from 0 to 5 seed per $0.1 \mathrm{~m}^{2}$, especially on the levees or near the edges of fields (D. O. TeBeest, unpublished data). Results indicate from this study that naturally infested seed on the soil surface could potentially be an important source of primary inoculum. However, further research is needed to compare qualitative and quantitative differences between artificially infested grain used in this study and naturally infested seed.

There has been little research on the qualitative and quantitative aspects of sporulation of the rice blast fungus on naturally infested seed (15). However, inoculum thresholds and survival are important parameters that affect primary inoculum $(2,8,17,23,28,31,33)$. Several studies have reported that $P$. grisea can be found on naturally infected seed on the outer seed embryo $(1,5,15,18,19,21)$. In this study, sporulation on artificially infested rice grain occurred for up to 2 weeks after deployment under field conditions and was coat and on all internal parts, except the

similar in overall appearance to that of naturally infested seed. Conidiophores and conidia formation were predominantly associated with the embryonic end of the rice seed for both artificially and naturally infested seed (data not shown). In a few cases, sporulation occurred on the entire seed coat for both the artificially and naturally infested seed. These results were similar to those of Chung and Lee (5) and others $(18,21)$, in that sporulation on naturally infested seed was usually confined to the embryonic end. Manandhar et al. (21) reported that sporulation can occur on all parts of the seed, especially if the seed is not viable. The only visible difference between the autoclaved seed and nonautoclaved seed in this study was the presence of minute crevices in the seed coats of autoclaved seed. This difference did not appear to be significant because the sul mutant was only allowed to grow on the seed for 7 days and did not colonize internal portions of the seed in that period.

The amount of inoculum on the soil surface at plant emergence affected when disease was first observed in both years. Leaf
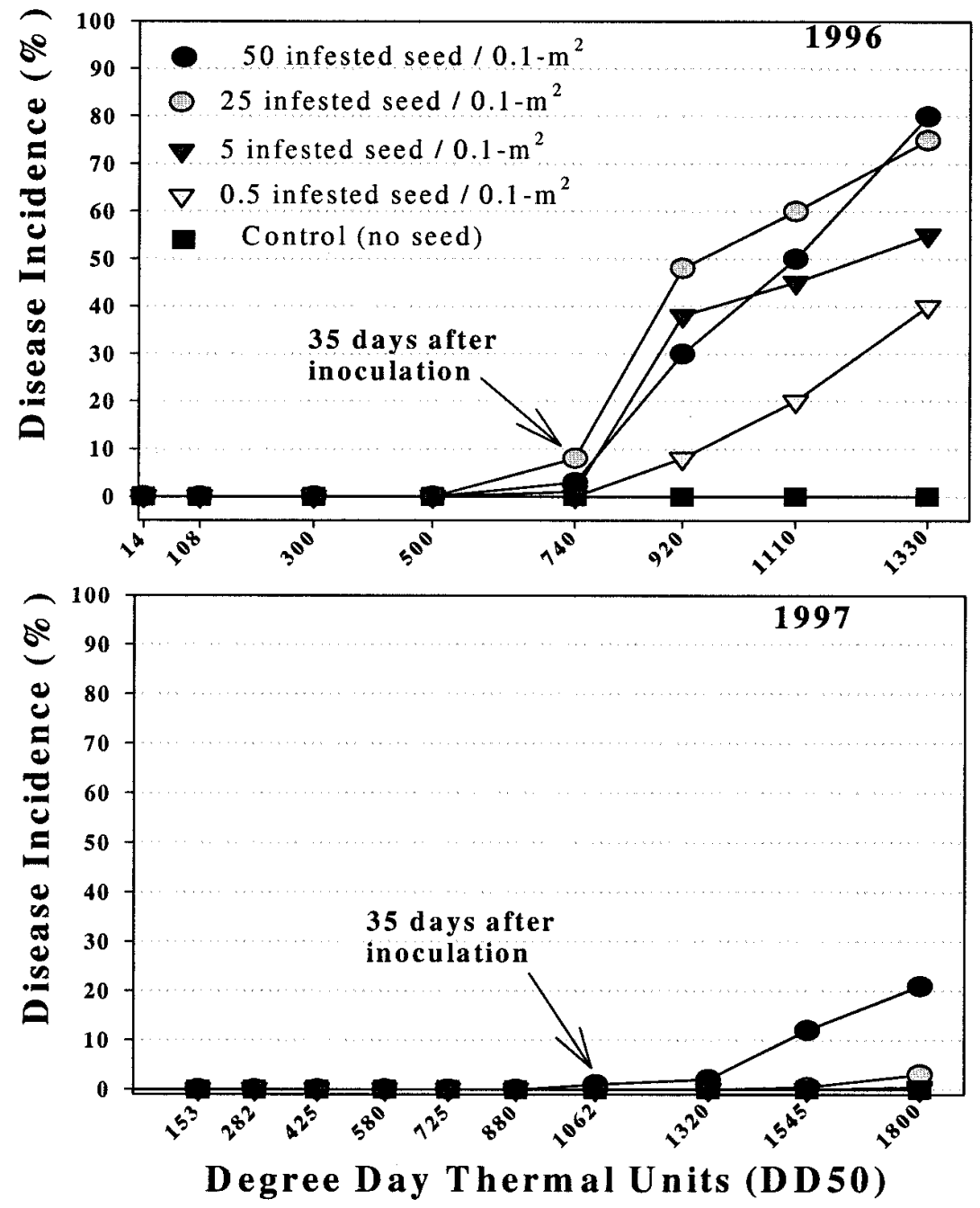

Fig. 2. Disease progress for leaf blast incidence (percent) on 'M-201' for different infested rice grain (number of infested grains per $0.1 \mathrm{~m}^{2}$ ) placed on the soil surface at plant emergence in 1996 and 1997. blast symptoms were first observed in the 25 (1996) and 50 (1996 and 1997) infested grain per $0.1-\mathrm{m}^{2}$ treatment 35 days after plant emergence, although physiological ages were substantially different at disease onset for the 2 years. In 1996, rice plants were in the active tillering stage after 35 days, whereas in 1997, the plants were already in early reproduction growth stage (panicle primordia). These data indicate that symptom development is more dependent on time of exposure to inoculum than on plant age. However, disease development after the initial onset of disease appeared to be influenced by plant maturity, because the maximum disease in 1996 (younger plants) was much higher than that observed in 1997 (older plants). Thus, the rate of initial disease development would be reduced if the initial onset of disease were delayed until plants were more mature $(4,12,16,27)$. These results support findings from Bastiaans (4) and Hwang et al. (12), in that leaf blast severity on younger plants is greater than that observed on older rice plants. Various management strategies such as planting date $(2,6)$ and reduction of primary inoculum $(2,6,15,25)$ could be beneficial in delaying rice blast epidemics and reducing subsequent yield loss.

The sul mutant of $P$. grisea was easily distinguished from wild-type isolates (background inoculum) recovered from rice blast lesions by a differential medium containing sodium selenate (10). The sul mtant predominated in all leaf, collar, and neck blast lesions sampled in 1996 and 1997, except for one sample at the end of the season in 1996. In 1996, a nearby rice blast fungicide trial was inoculated with $P$. grisea and heavy infection may have contributed to a high level of wild-type inoculum in the experimental plots. These observations confirmed that the inoculum originated from the infested rice grain deployed on the soil surface, and that the sul mutant both initiated and perpetuated the epidemic. The sul mutant and the parental wild-type isolate of $P$ grisea produced very similar disease progress curves on leaves under field conditions. Previous studies of sul mutants in the greenhouse confirmed that the virulence and aggressiveness of wild-type and sul mutants were similar with regard to infection efficiency, sporulation potential, and lesion size (D. H. Long, unpublished data). Harp and Correll (10) also reported that sul mutants of $P$. grisea were similar to their parental wild types in greenhouse tests and appeared stable after recovery from plant tissue. The use of marked strains of $P$. grisea could be useful in future epidemiological studies of rice blast.

Understanding the temporal and spatial dynamics of rice blast disease early in the season may be beneficial to developing effective management strategies in Arkansas. Currently, there are no testing procedures 
in Arkansas that address the level of seed infestation by $P$. grisea or the impact of infested seed on the early onset of disease. Theoretically, management of primary inoculum is more efficient in the management of monocyclic diseases (i.e., common smut of wheat) $(2,31)$ than for polycyclic diseases (i.e., rice blast) $(2,15,31)$. However, in all cases, the impact of all primary inoculum sources on the initial onset of disease must be addressed. If the management of infested seed could delay the early onset of disease and reduce its rate of development, as shown in this research, then perhaps other mechanisms (i.e., adult resistance) may be more useful in the management of rice blast.

\section{LITERATURE CITED}

1. Agarwal, P. C., Mortensen, C. N., and Mathur, S. B. 1989. Seed-borne diseases and seed health testing of rice. Pages 7-14 in: Danish Gov. Inst. Seed Pathol. Developing Countries, Denmark Tech. Bull. 3/CAB Int. Mycol. Inst. Phytopathol. Paper 30.

2. Agrios, G. N. 1997. Plant Pathology. 4th ed. Academic Press, San Diego, CA.

3. Babadoost, M., and Hebert, T. T. 1984. Incidence of Septoria nodorum in wheat seed and its effects on plant growth and yield. Plant Dis. 68:125-129.

4. Bastiaans, L. 1993. Understanding yield reduction in rice due to leaf blast. Ph.D. thesis. Agricultural University, Wageningen, the Netherlands.

5. Chung, H. S., and Lee, C. U. 1983. Detection and transmission of Pyricularia oryzae in germinating rice seed. Seed Sci. Technol. 11: 625-637.

6. Cloud, G. L., and Lee, F. N. 1993. Rice blast: Factors influencing severity and control strategies used to manage the disease. Ark. Coop. Ext. Misc. Pub. 341.

7. Filippi, M. C., and Prabhu, A. S. 1997. Integrated effects of host plant resistance and fungicidal seed treatment on rice blast control in Brazil. Plant Dis. 81:351-355.
8. Gabrielson, R. L. 1988. Inoculum thresholds of seedborne pathogens: Fungi. Phytopathology 78:868-872.

9. Gilbert, R. G., and Peaden, R. N. 1988. Dissemination of Verticillium albo-atrum in alfalfa by internal seed inoculum. Can. J. Plant Pathol. 10:73-77.

10. Harp, T. L., and Correll, J. C. 1998. Recovery and characterization of spontaneous, selenate-resistant mutants of Magnaporthe grisea, the rice blast pathogen. Mycologia 90:954-963.

11. Helms, R. S. 1990. Rice production handbook. Univ. Ark. Coop. Ext. Misc. Pub. 192.

12. Hwang, B. K., Koh, Y. J., and Chung, H. S. 1987. Effects of adult-plant resistance on blast severity and yield of rice. Plant Dis. 71:1035-1038.

13. Ishiguro, K. 1994. Using simulation models to explore better strategies for the management of blast disease in temperate rice pathosystems. Pages 435-450 in: Rice Blast Disease. R. S. Zeigler, S. Leong, and P. S. Teng, eds. CAB International, Wallingford, UK.

14. Kim, C. H., and Kim, C. K. 1990. Rice blast development under different water-management practices in fields in Korea. Korean J. Plant Pathol. 6:51-57.

15. Kingsolver, C. H., Barksdale, T. H., and Marchetti, M. A. 1984. Rice blast epidemiology. PA State Univ. Coll. Agric. Exp. Stn. Bull. 853.

16. Koh, Y. J., Hwang, B. K., and Chung, H. S. 1987. Adult-plant resistance of rice to leaf blast. Phytopathology 77:232-236.

17. Kuan, T. L. 1988. Inoculum thresholds of seedborne pathogens: Overview. Phytopathology 78:867-868.

18. Lamey, H. A. 1970. Pyricularia oryzae on rice seed in the United States. Plant Dis. Rep. 54:931-935.

19. Lee, F. N. 1994. Rice breeding programs, blast epidemics and blast management in the United States. Pages 489-500 in: Rice Blast Disease. R. S. Zeigler, S. Leong, and P. S. Teng, eds. CAB International, Wallingford, UK.

20. Long, D. H. 1996. The epidemiology of rice blast disease in Arkansas. M.S. thesis. University of Arkansas, Fayetteville.
21. Manandhar, H. K., Jørgensen, H. J. L. Smedegaard-Petersen, V., and Mathur, S. B. 1998. Seedborne infection of rice by Pyricularia oryzae and its transmission to seedlings. Plant Dis. 82:1093-1099.

22. Mayee, C. D. 1975. Perpetuation of Pyricularia oryzae Cav. through infected seeds in Vidarbha region. Indian Phytopathol. 27:604605.

23. Milus, E. A., and Chalkley, D. B. 1997. Effect of previous crop, seedborne inoculum and fungicides on development of Stagonospora blotch. Plant Dis. 81:1279-1283.

24. Nyvall, R. F., Percich, J. A., Porter, R. A., and Brantner, J. R. 1995. Comparison of fungal brown spot severity to incidence of seedborne Bipolaris oryzae and B. sorokiniana and infected floral sites on cultivated wild rice. Plant Dis. 79:249-250.

25. Ou, S. H. 1985. Rice Diseases. 2nd ed Commonw. Mycol. Inst., Kew, England.

26. Rossman, A. Y., Howard, R. J., and Valent, B. 1990. Pyricularia grisea, the correct name of the rice blast fungus. Mycologia 82:509-512.

27. Roumen, E. C. 1992. Effect of leaf age on components of partial resistance in rice to leaf blast. Euphytica 63:271-279.

28. Schaad, N. W. 1988. Inoculum thresholds of seedborne pathogen: Bacteria. Phytopathology 78:872-875.

29. Thrimurty, V. S., and Devadath, S. 1984. Role of seed in survival and transmission of Xanthomonas campestris pv. oryzae causing bacterial blight of rice. Phytopathol. Z. 110:15-19.

30. Torres, C. Q., and Teng, P. S. 1993. Path coefficient and regression analysis of the effects of leaf and panicle blast on tropical rice yield. Crop Prot. 12:296-302.

31. Van der Plank, G. E. 1963. Plant Disease: Epidemics and Control. Academic Press, New York.

32. Webster, R. K., and Gunnell, P. S. 1992. Compendium of Rice Diseases. The American Phytopathological Society, St. Paul, MN.

33. Xu, X.-M., and Ridout, M. S. 1998. Effect of initial epidemic conditions, sporulation rate, and spore dispersal gradient on the spatiotemporal dynamics of plant disease epidemics. Phytopathology 88:1000-1012. 